\title{
Photosynthesis in Porphyra tenera and Some Other Marine Algae as Affected by Tris(hydroxymethyl). aminomethane in Artificial Media
}

\author{
by Eizi OGata*
}

Received December 28, 1965.

A wide-range buffer medium ( $\mathrm{pH} 7.2$ to 9.0) containg tris(hydroxymethyl)aminomethane, $\left(\mathrm{CH}_{2} \mathrm{OH}\right)_{3} \mathrm{CNH}_{2}$, has been employed for algal cultures since Gomori ${ }^{1)}$ reported the usefulness of this buffer solution. The use of Tris (a currently prevailing abbreviation) buffer has recently been extended to cultures of marine algae in artificial sea water media, for which Provasoli et al. ${ }^{2)}$ made the first trial.

Iwasaki and Matsudaira ${ }^{3)}$ succeeded in culturing the free-living Conchocelis of Porphyra in screw-capped tubes containing an artificial sea water medium (ASP ${ }_{12} \mathrm{NTA}$ ), in which exogenous supply of carbon dioxide sources $\left(\mathrm{CO}_{2}\right.$, bicarbonate, and carbonate) for photosynthesis was absent and $\mathrm{pH}$ was adjusted with Tris buffer. On the other hand, Ogata ${ }^{4}$ reported that the free-living Conchocelis grew better in sea water enriched with bicarbonate than in the original bicarbonate-poor one. Moreover, the photosynthesis in Porphyra tenera and some other marine algae was remarkably enhanched by the addition of sodium bicarbonate $\left(\mathrm{NaHCO}_{3}, 5.0\right.$ to $\left.7.5 \mathrm{mM}\right)$ to the artificial sea water up to the $\mathrm{CO}_{2}$-saturation point $\left(\right.$ Ogata and Matsui $\left.{ }^{5}\right)$. The maximum photosynthetic rate of fresh marine algae was obtained when the total carbon dioxide $\left(\Sigma \mathrm{CO}_{2}\right)$ in the medium reached about 5.0 to $7.5 \mathrm{mM}$ under appropriate conditions with respect to illumination, temperature, and $\mathrm{pH}^{5}$.

These observations indicated that the photosynthesis in adult Porphyra tenera, its Conchocelis-phase, and some other marine algae is much affected by the surrounding conditions. Being led by this knowledge and the enhancement of photosynthesis in Tris-buffered artificial sea water entirely free from $\mathrm{CO}_{2}$, bicarbonate, and carbonate, investigation on the dependence of photosynthesis on Tris buffer in Porphyra and some other marine algae was carried out in more detail. The experiments were performed from late autumn of 1964 to early spring of 1965 .

\section{Materials and Methods}

Marine algae used were the red alga, Porphyra tenera, a commercially important species in Japan, a green alga Ulva pertusa, and a brown alga Petalonia fascia. Several pieces of algal bodies were cut out of Porphyra thalli, and they were divided to make $5 \sim 6$ sets of test material, each weighing $50 \mathrm{mg}$ in fresh weight. Materials of Ulva and Petalonia were excised out of mature thalli by means of a cork borer, $3 \mathrm{~cm}$ in diameter.

Measurement of true photosynthetic rate was carried out with the manometric technique after Umbreit et al. ${ }^{6)}$ modified by Ogata and Matsui ${ }^{5)}$. All the measurements were made at $20^{\circ}$ under 10 klux of illumination by incandescent lamps.

The final composition of the artifical sea water employed is shown in Table 1.

\footnotetext{
* Shimonoseki University of Fisheries, Yoshimi, Shimonoseki, Japan.
} 
Table 1. Composition of artificial sea water used as basal medium; Chlorinity, 18.5\%. Sodium bicarbonate ( 210 or $840 \mathrm{mg} / \mathrm{l}$ ) was added to the basal medium (final concentration, 2.5 or $10.0 \mathrm{mM}$, respectively).

\begin{tabular}{lc|lr}
\hline \hline $\mathrm{NaCl}$ & $23.5 \mathrm{~g} / l$ & $\mathrm{Na}_{2} \mathrm{HPO}_{4} \cdot 12 \mathrm{H}_{2} \mathrm{O}$ & $10 \mathrm{mg} / \mathrm{l}$ \\
$\mathrm{MgCl}_{2} \cdot 6 \mathrm{H}_{2} \mathrm{O}$ & $11.0 "$ & $\mathrm{NaF}$ & 3 " \\
$\mathrm{Na}_{2} \mathrm{SO}_{4}$ & $4.0 "$ & $\mathrm{EDTA} \cdot 2 \mathrm{Na}$ & $6.0 "$ \\
$\mathrm{CaCl}_{2}$ & $700 \mathrm{mg} / l$ & $\mathrm{MnCl}_{2} \cdot 4 \mathrm{H}_{2} \mathrm{O}$ & $0.864 "$ \\
$\mathrm{KCl}$ & $600 "$ & $\mathrm{FeCl}_{3} \cdot 6 \mathrm{H}_{2} \mathrm{O}$ & $0.772 "$ \\
$\mathrm{KBr}$ & $100 "$ & $\mathrm{ZnCl}_{2}$ & $0.061 "$ \\
$\mathrm{SrCl}_{2} \cdot 6 \mathrm{H}_{2} \mathrm{O}$ & $40 "$ & $\mathrm{CoCl}_{2} \cdot 6 \mathrm{H}_{2} \mathrm{O}$ & $0.024 "$ \\
$\mathrm{H}_{3} \mathrm{BO}_{3}$ & $30 "$ & $\mathrm{CuSO}_{4} \cdot 5 \mathrm{H}_{2} \mathrm{O}$ & $0.005 "$ \\
$\mathrm{NaNO}_{3}$ & $20 "$ & & \\
\hline
\end{tabular}

As the sole carbon source, $\mathrm{NaHCO}_{3}$ was added to this artificial medium at the concentrations from 0 to $10 \mathrm{mM}$. Tris buffer (final concentration, 0 to $7.5 \mathrm{mM}$ ) was added to bicarbonate-free or -enriched media. These media prepared were stored in $300 \mathrm{~m} l$ Erlenmeyer flasks tightly covered with paraffin paper and tied with a rubber band.

Total carbon dioxide $\left(\sum \mathrm{CO}_{2}\right)$ was measured by means of the modified technique after Conway ${ }^{7)}$, Saruhashi ${ }^{8)}$, and Saijo (unpublished data), using diffusion apparatus of a large capacity $(350 \mathrm{~m} l$, outer section; $75 \mathrm{ml}$, inner section) and 25 or $50 \mathrm{~m} l$ of sample medium. The $\mathrm{CO}_{2}$ was evaporated from the sample by acidifying the solution with $2 \sim 3$ drops of $1 \mathrm{~N} \mathrm{H}_{2} \mathrm{SO}_{4}$. After 24 hrs's incubation of the diffusion cell at room temperature, the $\mathrm{CO}_{2}$ absorbed in $\mathrm{N} / 20$ baryta solution placed in the inner section was titrated with $\mathrm{N} / 40 \mathrm{HCl}\left(\sum \mathrm{CO}_{2}\right)$.

The value of $\mathrm{pH}$ was measured each time immediately after preparation of medium or immediately before the experiment.

\section{Results}

1. True photosynthesis in Porphyra as affected by Tris buffer.

The Tris buffer reagent in these experiments was added to the basal and bicarbonate-enriched media $24 \mathrm{hrs}$. before the measurement. Photosynthesis in the basal bicarbonate-free medium containing Tris buffer in various concentrations is represented by Curve A in Fig. 1. The photosynthesis is apparently enhanced by the addition of $1 \mathrm{mM}$ or more of Tris buffer. Curve $B$ in the same figure shows the photosynthesis in the presence of $2.5 \mathrm{mM}$ of bicarbonate to which Tris buffer in increasing concentrations was added. The maximum rate appears at $2.5 \mathrm{mM}$ of the Tris buffer. The photosynthesis in the presence of $10 \mathrm{mM}$ of bicarbonate as represented by Curve $\mathrm{C}$ in Fig. 1 indicate that the addition of Tris buffer does not so much change the photosynthetic level in the absence of Tris buffer. The addition of Tris buffer more or less changed the $\mathrm{pH}$ as shown in Table 2. The effect of $\mathrm{pH}$ change and $\mathrm{CO}_{2}$-retention by the addition of Tris buffer on the photosynthetic activity is shown in Fig. 6. It will be seen from the comparison of these data that the changes in $\mathrm{pH}$ of the medium is not the direct cause of the observed effects of Tris buffer.

2. Apparent photosynthesis in Porphyra as affected by Tris buffer in a long-stored medium.

When the experiments were made with the identical but long-stored media, the trends as described above were, however, somewhat changed as represented in Fig. 2, 


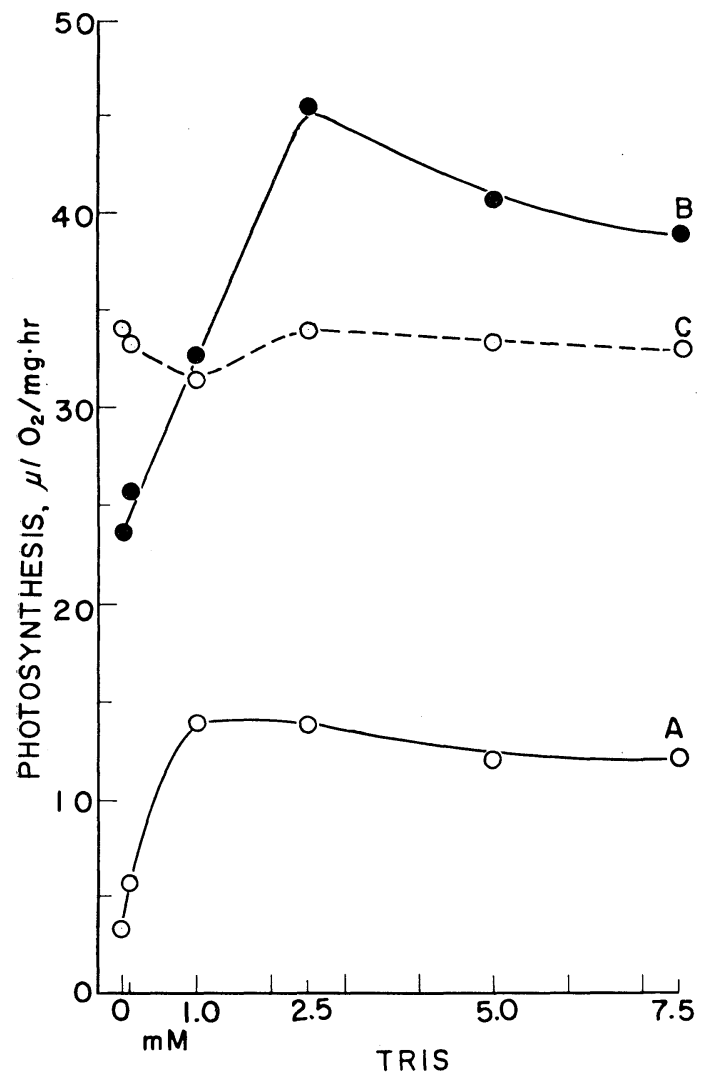

Fig. 1. True photosynthesis of Porphyra tenera in Tris-buffered media. Curve A, in bicarbonate-free basal medium; Curve $\mathrm{B}$, in bicarbonate-supplemented $(2.5 \mathrm{mM})$ medium; Curve $\mathrm{C}$, in bicarbonate-rich $(10 \mathrm{mM})$ medium, Each medium was prepared 24 hrs. before the experiment.

Table 2. The $\mathrm{pH}$ values in various media used for experiments in Fig. 1 (upper line in each row) and in Fig. 2 (lower line in each row) measured just before the experiment.

\begin{tabular}{c|rccccc|r}
\hline $\begin{array}{c}\text { Conc. of Tris } \\
\text { buffer (mM) }\end{array}$ & 0 & 0.1 & 1.0 & 2.5 & 5.0 & 7.5 & $\begin{array}{c}\text { Storage in } \\
\text { days }\end{array}$ \\
\hline Medium & 5.9 & 6.9 & 8.3 & 8.6 & 8.9 & 9.0 & 1 \\
\hline $\begin{array}{c}\mathrm{NaHCO}_{3} \text {-free } \\
\text { medium }\end{array}$ & 5.9 & 6.5 & 7.4 & 7.7 & 8.0 & 8.1 & 30 \\
\hline $\mathrm{NaHCO}_{3}(2.5 \mathrm{mM})$ & 7.6 & 7.6 & 8.0 & 8.4 & 8.7 & 8.8 & 1 \\
medium & 7.8 & 7.8 & 7.9 & 8.0 & 8.1 & 8.2 & 19 \\
\hline $\mathrm{NaHCO}_{3}(10 \mathrm{mM})$ & 7.9 & 8.0 & 8.1 & 8.2 & 8.4 & 8.5 & 1 \\
medium & 8.2 & 8.3 & 8.3 & 8.3 & 8.3 & 8.3 & 20 \\
\hline
\end{tabular}


on the basis of apparent photosynthesis. Note the difference of the base for photosynthesis between Figs. 1 and 2. Apparent photosynthesis in Fig. 2 was measured during 30 minutes, so the rates were about one-half of those in true photosynthesis in Fig. 1. The apparent photosynthetic rate was preferred to the true rate because the effect of Tris buffer is detected in the former as well as in the latter, and because

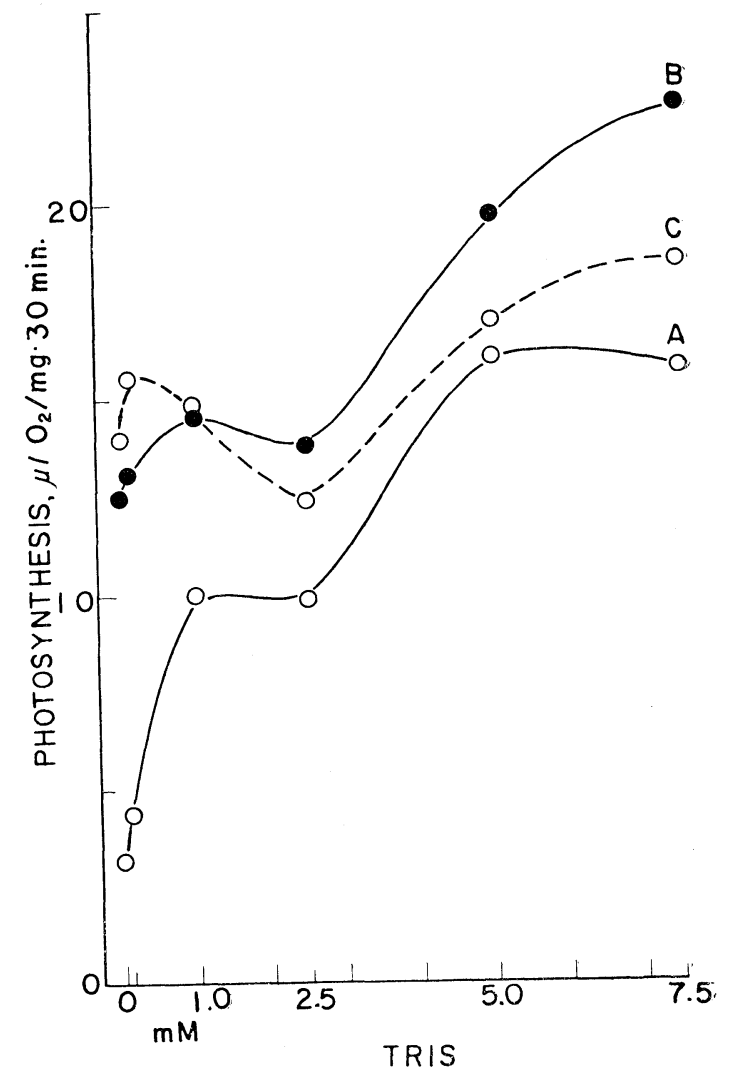

Fig. 2. Apparent photosynthesis of Porphyra tenera in Tris-buffered media. See Fig. 1 for further legends. Media were prepared 30, 19 , and 20 days before the experiment, respectively.

the measurement is much more convenient in the former which does not acquire the correction for respiration.

The apparent photosynthetic rate in the basal, bicarbonate-free medium (Curve A in Fig. 2) increased more markedly on addition of Tris buffer than the true rate shown in Fig. 1. The increase was more conspicuous in the upper range of Tris concentration such as 5.0 and $7.5 \mathrm{mM}$.

The effect of Tris buffer, however, became irregular in bicarbonate-supplemented media. The rates in $2.5 \mathrm{mM} \mathrm{NaHCO}$ medium were more greatly enhanced by the high concentration of Tris buffer than in the case of Fig. 1 as indicated by the Curve $\mathrm{B}$ in Fig. 2. The rates in $10 \mathrm{mM} \mathrm{NaHCO}$ medium became rather irregular as shown by the Curve $\mathrm{C}$ in the same figure. And these two curves were closely approached by the curve for basal medium with Tris buffer. These changes in response to Tris 
buffer in Fig. 2 were obtained under the experimental conditions identical with those in the case of Fig. 1 but for a rather long lapse of time after the preparation of the media. The time lapse and $\mathrm{pH}$ shift are presented in Table 2.

3. Photosynthesis in Porphyra as influenced by aging of the medium.

The observations indicate that the aging of the medium after preparation is an important factor for such changes. Thus, successive measurements of photosynthesis as affected by Tris buffer along the aging of the medium were made, employing only the

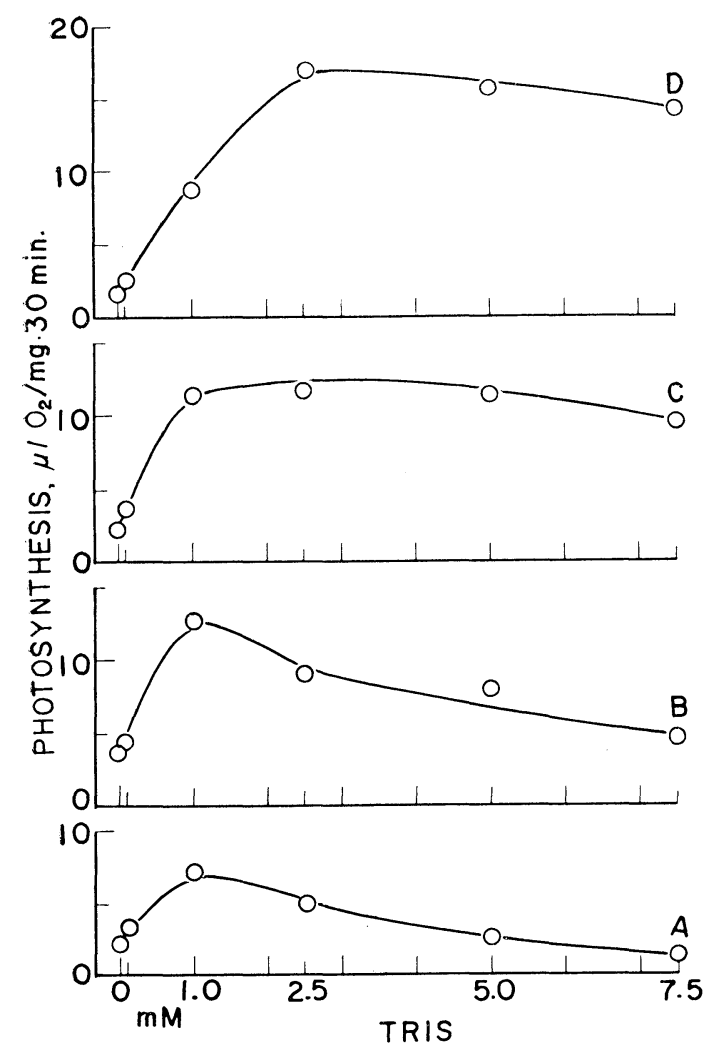

Fig. 3. Apparent photosynthesis of Porphyra tenera in Tris-buffered bicarbonate-free basal medium immediately after preparation (A), after 1 day (B), after 8 days (C), and after 15 days (D).

Table 3. Shift of $\mathrm{pH}$ in Tris-buffered basal media with time of storage after preparation.

\begin{tabular}{c|cccccc}
\hline \hline $\begin{array}{c}\text { Conc. of Tris } \\
\text { buffer }(\mathrm{mM})\end{array}$ & 0 & 0.1 & 1.0 & 2.5 & 5.0 & 7.5 \\
Storage in days & & & & & & \\
\hline 0 & 5.8 & 6.7 & 8.5 & 8.9 & 9.1 & 9.3 \\
1 & 5.8 & 6.5 & 8.4 & 8.7 & 9.1 & 9.3 \\
8 & 5.8 & 6.3 & 7.3 & 8.2 & 8.6 & 8.7 \\
15 & 5.8 & 6.2 & 7.0 & 7.5 & 8.0 & 8.5 \\
\hline
\end{tabular}


basal medium without any supply of $\mathrm{NaHCO}_{3}$ (Fig. 3). Time of aging and $\mathrm{pH}$ shift in the Tris-buffered basal medium are presented in Table 3.

Just after the preparation, an enhancement of photosynthesis was observed at $1 \mathrm{mM}$ concentration of Tris buffer, but the extent was very little. After 1 day, the rate at $1.0,2.5$, and $5.0 \mathrm{mM}$ rose more greatly than before also with significant peak at $1 \mathrm{mM}$. This peak diminished and a rather flat plateau appeared after 8 days of storage, reflecting the great extents of enhancement at higher concentration of the buffer, 2.5, 5.0 , and $7.5 \mathrm{mM}$. The optimum concentration was shifted to $2.5 \mathrm{mM}$ of Tris buffer with 15 days old medium.

It is apparent from the above-described facts that the rate of photosynthesis is enhanced with increasing age of the buffered medium, and that at first the optimum concentration for the enhancement lies at $1 \mathrm{mM}$ but later becomes much higher, i.e. $2.5 \mathrm{mM}$.

4. Photosynthesis in other algal species as affected by Tris buffer.

The experiment was later extended to several other marine algae. Ulva pertusa. (Fig. 4) tested in long-stored media showed almost the same response as Porphyra.

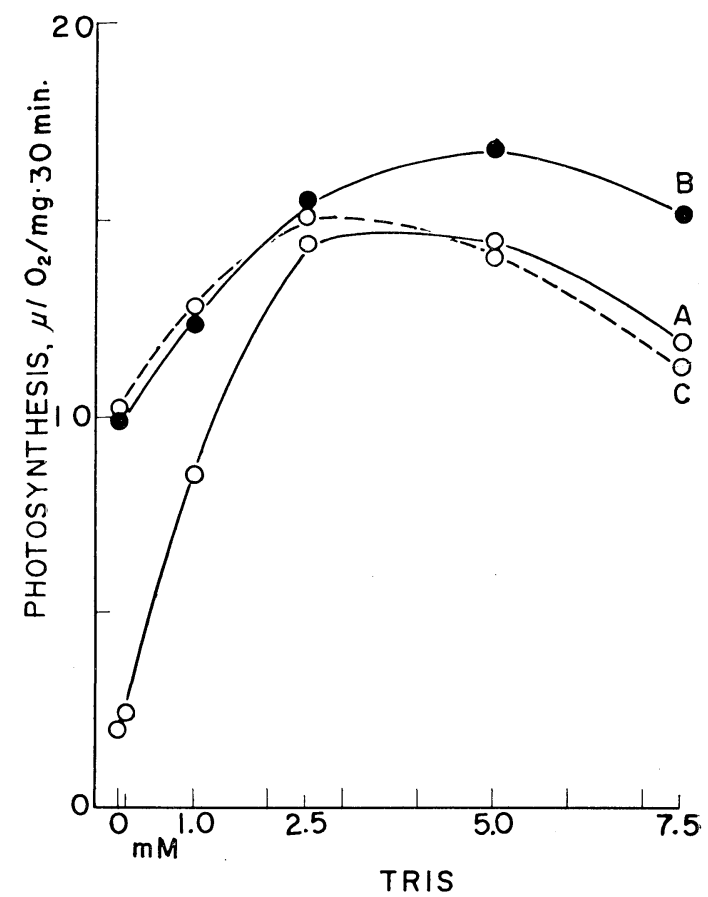

Fig. 4. Apparent photosynthesis of Ulva pertusa in Tris-buffered media. See Fig. 1 for further legends. Media were prepared 45,35 , and 36 days before the experiment.

(Fig. 2) except for some minor details. Moreover, the rate in the basal medium was: promoted by increasing concentrations of Tris buffer to reach a level attained in the same basal medium fortified with bicarnonate in sufficient $(2.5 \mathrm{mM})$ or abundant $(10 \mathrm{mM})$ concentration.

Similar trend was observed between the case of a brown alga Petalonia fascia 
(Fig. 5) and of Porphyra tenera (Fig. 1). In this brown alga, the experiments were made using one-day old medium as was the case with Porphyra in Fig. 1. Except for some minor difference, the behavior of the two species were almost identical. The photosynthetic rates were enhanced to some extent with increasing concentration of the buffer reagent.

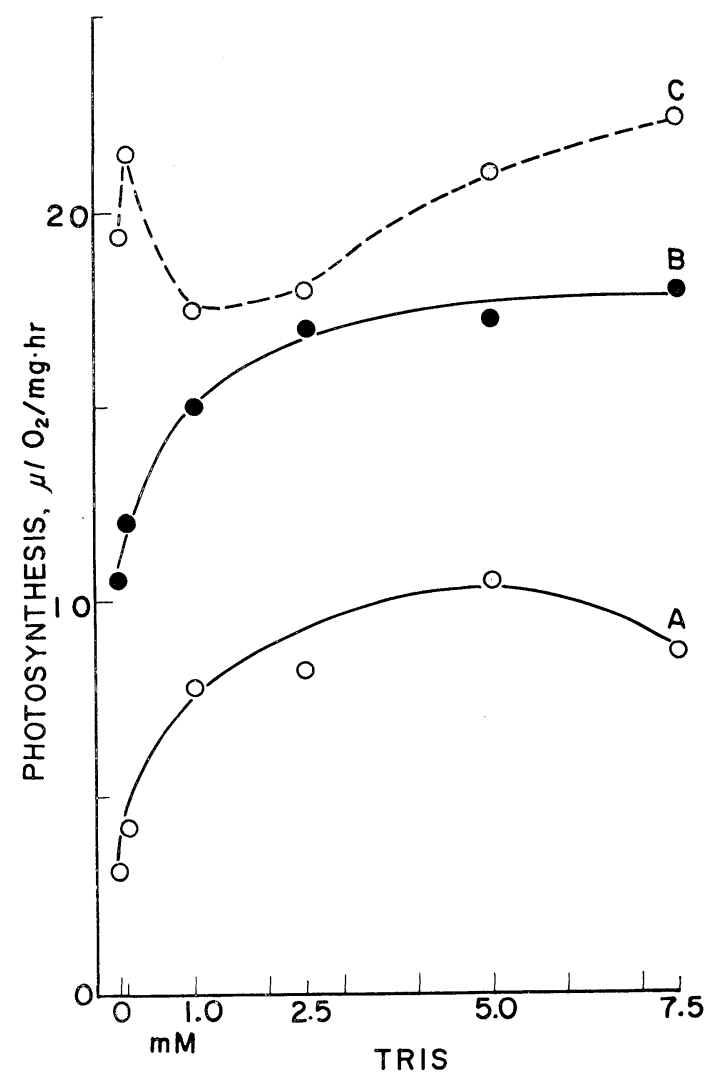

Fig. 5. True photosynthesis of Petalonia fascia in Tris-buffered media. See Fig. 1 for further legends. Each medium was prepared $24 \mathrm{hrs}$. before the experiment.

5. Photosynthesis in Porphyra as affected by $\mathrm{pH}$.

It has been well known that the photosynthesis is much affected by pH irrespective of the nature of the buffering reagent. The effect of Tris buffer might have arisen from the change in $\mathrm{pH}$. The plain basal medium which showed $\mathrm{pH} 5.8$ to 6.0 was rendered alkaline by the addition of Tris buffer, but later turned back somewhat acid when the mixture had been stored long. Bicarbonate-supplemented media, containing Tris buffer, on the contrary, maintained a fairly stable $\mathrm{pH}$ level even after long storage as seen in Table 2. The photosynthesis in fresh and long-stored-N/20 Tris buffer solution prepared after Gomori's prescription ${ }^{1)}$ was measured in this connection.

The results presented in Fig. 6 indicate that the photosynthesis in a long-stored 
buffer solution is markedly higher than that in a fresh one, both showing maximum rate at $\mathrm{pH}$ 8.6. This $\mathrm{pH}$ optimum, however, appears to be unusually high in comparison with those (8.0 or slightly lower) ordinarily found in phosphate and carbonatebicarbonate mixtures with Porphyra, Ulva, Gelidium, and Zostera ${ }^{9)}$.

Experiments for comparison were made in the basal medium, of which the $\mathrm{pH}$ was adjusted with 0.1 to $0.2 \mathrm{~m} l$ of $\mathrm{N} / 50 \mathrm{HCl}$ and $\mathrm{N} / 50 \mathrm{NaOH}$ solutions without any supply of Tris buffer or bicarbonate. The pH level thus obtained, however, was less stable than that in the Tris-buffered or bicarbonate-supplemented media. The results shown in Table 4 indicate that the rise in $\mathrm{pH}$ alone does not make the cause of the acceleration of photosynthesis, unless there is an additional supply of carbon dioxide.

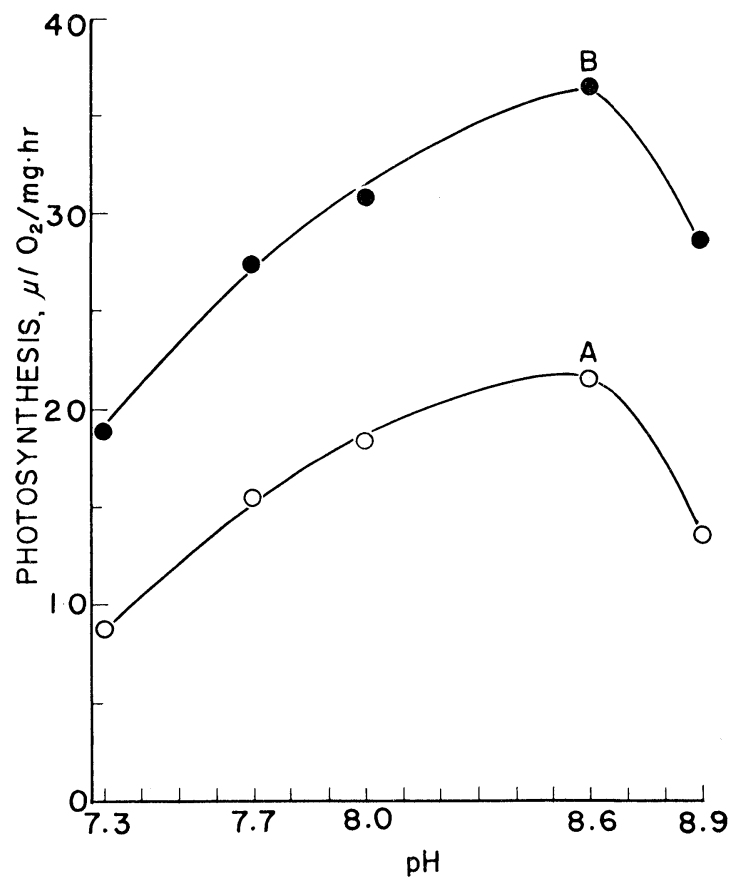

Fig. 6. True photosynthesis of Porphyra tenera as affected by $\mathrm{pH}$ in $N / 20$ Tris buffer solutions and by time lapse after the preparation of these buffers. Curve $\mathrm{A}$ : stored for 1 day; curve $\mathrm{B}$ : for 45 days.

Table 4. Apparent photosynthesis in Porphyra tenera in basal medium (bicarbonate-free) as affected by $\mathrm{pH}$.

\begin{tabular}{l|cccccc}
\hline \hline $\begin{array}{l}\mathrm{pH} \text { immediately before } \\
\text { the experiment }\end{array}$ & 5.8 & 6.4 & 7.7 & 8.0 & 8.3 & 8.9 \\
\hline $\begin{array}{l}\text { Photosynthesis } \\
\mu l 0_{2} / \text { mg. } 30 \text { min. }\end{array}$ & 1.4 & 2.1 & 2.6 & 3.0 & 3.0 & 3.3 \\
\hline $\begin{array}{l}\text { pH } 3 \text { hrs. after the } \\
\text { experiment }\end{array}$ & 5.8 & 6.1 & 6.6 & 6.8 & 7.3 & 8.2 \\
\hline
\end{tabular}

$\mathrm{pH}$ of the medium was adjusted by addition of $\mathrm{N} / 50 \mathrm{HCl}$ and $\mathrm{N} / 50 \mathrm{NaOH}$ solutions. 
It is apparent that the presence of Tris buffer, or the change induced by long storage of the buffer solution, is responsible for the enhancement of photosynthesis under these conditions. These facts suggest that the enhancement of photosynthesis by the presence of Tris buffer may be caused by the retention of carbon source for photosynthesis by means of $\mathrm{CO}_{2}$-absorbing action by Tris buffer.

6. Level of $\Sigma \mathrm{CO}_{2}$ in Tris-buffered media.

Assuming that the addition of Tris buffer favors the increase in available carbon dioxide source, the amount of $\Sigma \mathrm{CO}_{2}$ were determined in various media, namely hithero employed ones, differing in Tris concentration, $\mathrm{pH}$, and length of storage.

Tables 5 and 6 show that $\Sigma \mathrm{CO}_{2}$ rises with increasing concentration of Tris buffer

Table 5. Changes in $\sum \mathrm{CO}_{2}$ during storage of basal media containing Tris buffer.

\begin{tabular}{l|llllll|c}
\hline $\begin{array}{c}\text { Conc. of Tris buffer } \\
(\mathrm{mM})\end{array}$ & 0 & 0.1 & 1.0 & 2.5 & 5.0 & 7.5 & $\begin{array}{c}\text { Storage } \\
\text { in days }\end{array}$ \\
\hline $\mathrm{pH}$ & 6.2 & 6.5 & 7.3 & 7.7 & 8.0 & 8.2 & 25 \\
$\sum \mathrm{CO}_{2}(\mathrm{mM})$ & 0.25 & 0.50 & 1.80 & 2.10 & 3.40 & 4.00 & 25 \\
\hline $\mathrm{pH}$ & 6.2 & 6.7 & 7.5 & 7.9 & 8.0 & 8.2 & 5 \\
$\sum \mathrm{CO}_{2}(\mathrm{mM})$ & 0.45 & 1.00 & 1.35 & 2.20 & 5.60 & 8.30 & 54 \\
\hline
\end{tabular}

Table 6. $\sum \mathrm{CO}_{2}$ and $\mathrm{pH}$ as affected by Tris buffer in bicarbonatesupplemented media.

\begin{tabular}{c|l|rrrrrr|c}
\hline \hline \multicolumn{2}{c}{$\begin{array}{c}\text { Conc. of Tris } \\
\text { buffer }(\mathrm{mM})\end{array}$} & 0 & 0.1 & 1.0 & 2.5 & 5.0 & 7.5 & $\begin{array}{c}\text { Storage } \\
\text { in days }\end{array}$ \\
\hline $\begin{array}{c}\text { Medium } \\
\mathrm{NaHCO}_{3}(2.5 \mathrm{mM})\end{array}$ & $\mathrm{pH}$ & 7.6 & 7.6 & 7.7 & 7.8 & 8.0 & 8.0 & 5 \\
medium & $\sum \mathrm{CO}_{2}(\mathrm{mM})$ & 2.3 & 2.6 & 3.7 & 4.4 & 7.5 & $>8.0$ & 55 \\
\hline $\begin{array}{c}\mathrm{NaHCO}_{3}(10 \mathrm{mM}) \\
\text { medium }\end{array}$ & $\mathrm{pH}$ & 8.5 & 8.5 & 8.5 & 8.5 & 8.5 & 8.5 & 54 \\
\hline
\end{tabular}

and also with increasing sum of Tris and bicarbonate. In the bicarbonate-saturated medium, however, the addition of Tris buffer does not essentially increase the $\Sigma \mathrm{CO}_{2}$.

The results thus far obtained in the photosynthesis measurements are quite consistent with the results of $\Sigma \mathrm{CO}_{2}$ analyses and appear to support the assumption that the enhancing effect of Tris buffer under discussion is caused by the improvement in the $\mathrm{pH}$ condition and the increase in $\Sigma \mathrm{CO}_{2}$.

7. Level of $\Sigma \mathrm{CO}_{2}$ in $\mathrm{N} / 20$ Tris buffer solution.

The level of $\Sigma \mathrm{CO}_{2}$ in $\mathrm{N} / 20$ Tris buffer solution prepared after Gomori ${ }^{1)}$ was investigated to elucidate the unusually high $\mathrm{pH}$ optimum (8.6) of photosynthesis as shown in Fig. 6. The results in Table 7 indicate that $\Sigma \mathrm{CO}_{2}$ increases with elevated $\mathrm{pH}$, despite of elsewise identical composition of the buffer solutions. This increase was in parallel with the increasing rate of photosynthesis in a $\mathrm{pH}$ range from 7.3 to 8.6, but the photosynthesis declined at $\mathrm{pH}$ 8.9. This decline is probably due to the excessively high $\mathrm{pH}$. 
Table 7. $\sum \mathrm{CO}_{2}$ and $\mathrm{pH}$ in $\mathrm{N} / 20$ Tris buffer solution after 77 days' storage.

\begin{tabular}{l|rrrrrr}
\hline $\mathrm{pH}$ & 7.3 & 7.7 & 8.0 & 8.3 & 8.6 & 8.9 \\
\hline$\sum \mathrm{CO}_{2}(\mathrm{mM})$ & 2.5 & 5.0 & 7.0 & 8.0 & 11.1 & 15.8 \\
\hline
\end{tabular}

8. Changes in $\Sigma \mathrm{CO}_{2}$ during storage of Tris-buffered media.

The $\Sigma \mathrm{CO}_{2}$ determinations were also made with Tris-buffered basal media (1.0, $2.5,5.0$, and $0 \mathrm{mM}$ Tris) in a fresh condition and after various length of storage of the medium. The media tested had been stored in $300 \mathrm{~m} l$ Erlenmeyer flasks with glass stoppers. As will be seen in Table 8, a gradual increase in $\Sigma \mathrm{CO}_{2}$ and lowering in $\mathrm{pH}$ occurred with storage. However, the extent of the change was less than that found in earlier experiments such as those shown in Table 5. The difference is perhaps due to the more tight insulation from the surrounding atmosphere. Indeed, both the increase in $\Sigma \mathrm{CO}_{2}$ and the lowering in $\mathrm{pH}$ were furthered by a short bubbling with an air pump even after 34 days of storage (bottom line in Table 8). It is almost clear that the Tris-buffered media have absorbed carbon dioxide from the surrounding air.

Table 8. Successive change of $\sum \mathrm{CO}_{2}$ and $\mathrm{pH}$ in basal medium as affected by Tris buffer and by aeration.

\begin{tabular}{|c|c|c|c|c|c|c|c|c|}
\hline & \multicolumn{4}{|c|}{$\mathrm{pH}$} & \multicolumn{4}{|c|}{$\sum \mathrm{CO}_{2}(\mathrm{mM})$} \\
\hline $\begin{array}{l}\text { Storage } \\
\text { in days }\end{array}$ & 0 & 1.0 & 2.5 & 5.0 & 0 & 1.0 & 2.5 & 5.0 \\
\hline 0 & 5.9 & 8.5 & 8.9 & 9.2 & 0 & 0.30 & 0 & 0 \\
\hline 1 & 5.9 & 8.5 & 8.8 & 9.1 & 0 & 0.95 & 0.70 & 0.05 \\
\hline 7 & 5.9 & 8.2 & 8.7 & 9.1 & 0.20 & 1.00 & 0.50 & 0.40 \\
\hline 33 & 5.9 & 7.5 & 8.1 & 8.6 & 0.55 & 1.05 & 1.15 & 1.65 \\
\hline Air bubbling (1.5 hrs.) & 5.9 & 7.4 & 7.8 & 8.1 & 0.25 & 1.05 & 1.65 & 2.30 \\
\hline
\end{tabular}

Table 9. Photosynthesis in Ulva pertusa, in Tris-buffered basal medium as affected by air-tightness of vessels, removal of free $\mathrm{CO}_{2}$, and supply of air.

\begin{tabular}{|c|c|c|c|c|c|c|c|}
\hline $\begin{array}{l}\text { Conc. of Tris buffer } \\
(\mathrm{mM})\end{array}$ & 0 & 2.5 & 2.5 & 2.5 & 2.5 & 0 & \multirow{2}{*}{$\begin{array}{l}\text { Storage } \\
\text { in days }\end{array}$} \\
\hline $\begin{array}{l}\text { Air tightness or } \\
\text { aeration }\end{array}$ & Open & $\begin{array}{l}\mathrm{CO}_{2-}^{-} \\
\text {free }\end{array}$ & $\begin{array}{l}\text { Covered } \\
\text { with } \\
\text { paper }\end{array}$ & Open & $\underset{\text { bubbling }}{\text { Air }}$ & $\underset{\text { bubbling }}{\text { Air }}$ & \\
\hline $\mathrm{pH}$ & 5.9 & 8.9 & 8.7 & 8.6 & 8.4 & - & \multirow{3}{*}{1} \\
\hline $\begin{array}{l}\text { Photosynthesis } \\
\left(\mu l 0_{2} / \mathrm{mg} .30 \mathrm{~min} .\right)\end{array}$ & 1.4 & 2.2 & 3.6 & 3.9 & 11.1 & - & \\
\hline$\sum \mathrm{CO}_{2}(\mathrm{mM})$ & 0.10 & 0.10 & 0.20 & 0.75 & 1.35 & - & \\
\hline $\mathrm{pH}$ & 5.9 & 8.9 & 8.0 & 8.0 & 7.8 & 6.4 & \multirow{3}{*}{7} \\
\hline $\begin{array}{l}\text { Photosynthesis } \\
\left(\mu l \mathrm{O}_{2} / \mathrm{mg} .30 \mathrm{~min} .\right)\end{array}$ & 1.2 & 2.1 & 7.2 & 7.7 & 8.1 & 1.6 & \\
\hline$\sum \mathrm{CO}_{2}(\mathrm{mM})$ & 0.15 & 0.50 & 2.10 & 2.00 & 2.50 & 0.90 & \\
\hline
\end{tabular}


9. Increase of $\Sigma \mathrm{CO}_{2}$ as affected by aeration.

Determinations in more details were made in relation to the insulation from, and. contact with, the surrounding atmosphere, to the level of $\Sigma \mathrm{CO}_{2}$ in the media under loose and tight closures and with or without aeration, and to the complete removal of carbon dioxide by $15 \% \mathrm{KOH}$ solution. As shown in Table 9, the photosynthetic rate in Ulva pertusa for the test material present a good parallerism with the level. of $\Sigma \mathrm{CO}_{2}$ in the respective media stored in various vessels under varied air-tightness.

\section{Discussion}

The presence of Tris buffer in the medium generally favors photosynthesis and growth of marine algae. Such effects arise, however, from complicated changes in chemical composition in the Tris-buffered media. One of the favorite effect for photosynthesis is the shift of $\mathrm{pH}$ toward alkalinity in the bicarbonate-free basal medium. In fact, the initial $\mathrm{pH}$ in the bicarbonate-free basal medium is too low. Subsequently, the initial $\mathrm{pH}$ in such medium is to be brought to the optimal $\mathrm{pH}$ by addition of Tris buffer, unless bicarbonate-salt is employed for $\mathrm{pH}$ regulation. Another effect, which cannot be accounted for by $\mathrm{pH}$ change, is that the addition of Tris buffer promotes the absorption of carbon dioxide from the surrounding atmosphere and thus increases the $\sum \mathrm{CO}_{2}$, namely, the amount of available carbon dioxide supply. Recently, Wiedeman ${ }^{10)}$ reported on the non-utilization of Tris as a direct carbon source in the growth of green algae, and McLachlan ${ }^{11)}$ also did on some effects of Tris on the growth of Haematococcus pluvialis. These do not conflict with the results obtained in the present work. Galloway and Krauss ${ }^{12)}$ also observed marked $\mathrm{pH}$ change in Tris-buffered media on streaming with $\mathrm{CO}_{2}$-containing air. This over-all view is substantiated by various experiments with varying bicarbonate supplementation, insulation from air, forced exogenous supply (bubbling) of carbon dioxide, and length of storage of the media.

The widely deviating results encountered in the present study on photosynthesis in marine algae might probably due to the circumstance revealed by the present work that the nature of the Tris-buffered medium is subject to a wide deviation depending on the active $\mathrm{CO}_{2}$-retention by the addition of Tris buffer as a result of unavoidable absorption of carbon dioxide from the surrounding atmosphere.

To overcome such uncertainties, the addition of bicarbonate to basal medium for carbon dioxide supply is preferable first of all because of the stability of the medium. with respect to $\mathrm{pH}$ and $\mathrm{CO}_{2}$ content. At the same time, it is recommendable to determine the $\mathrm{pH}$ and $\Sigma \mathrm{CO}_{2}$ each time before use. The same appears to hold true for the photosynthesis investigation of algae and other plants in fresh water.

The authors wishes to express his sincere thanks to Prof. S. Nagai, Nara Women's University, for his continuous guidance and most valuable suggestions. Thanks are also due to the usefull suggestions given by Mr. K. Takesue concerning the techniques of $\Sigma \mathrm{CO}_{2}$ estimation.

\section{Summary}

Photosynthetic activity of marine algae such as Porphyra, Ulva, and Petalonia was found to be enhanced by the addition of Tris buffer to the artificial sea water. This enhancing effect of Tris buffer is mainly accounted for by increased supply of available 
carbon dioxide. The Tris-buffered media undergo remarkable lowering in $\mathrm{pH}$ due to the absorption of carbon dioxide from the surrounding atmosphere.

Prolonged storage of the medium after preparation allows these changes to proceed further and makes the enhancing effect of Tris buffer more conspicuous. Increasing addition of Tris buffer renderes the medium somewhat alkaline and often favors photosynthesis. The $\mathrm{pH}$ changes alone cannot account for the enhancement. The increase in amount of carbon source in the medium seems to be cardinal in causing the enhancing effect.

\section{References}

1) Gomori, G., Proc. Soc. Exptl. Biol. Med. 62: 33 (1946). 2) Provasoli, L., McLaughlin, J.J.A., and Droop, M. R., Archv f. Microbiol. 25: 392 (1957). 3) Iwasaki H., and Matsudaira, C., Biol. Bull. 124: 268 (1963). 4) Ogata, E., J. Shimonoseki Coll. Fish. 10: 423 (1961). 5) Ogata, E., and Matsui, T., Jap. Journ. Bot. 19: 83 (1965). 6) Umbreit, W., Burris, H. R., and Stauffer, J.R., Manometric Techniques, 83 (Burgess Publishing Co., Minneapolis, 1957). 7) Conway, E., Microdiffusion Analysis and Volumetric Error, 208 (Crosby Lockwood and Son Ltd., London, 1950). 8) Saruhashi, K., Meteor. Geophys. 6: 38 (1955). 9) Ogata, E., and Matsui, T., Botanica Marina 8: 199 (1965). 10) Wiedeman, V. E., Canad. J. Bot. 42: 1581 (1964). 11) McLachlan, J., ibid. 41: 35 (1963). 12) Galloway R. A., and Krauss, W., Plant and Cell Physiol. 2: 331 (1961).

\section{摘 要 \\ 尾形英二：人工海水中における海藻の光合成におよぼす トリス・ヒドロキシメチル・アミノメタンの影響}

最近海藻の培養液として,トリス・ヒドロキシメチル・アミノメタン $\left(\mathrm{CH}_{2} \mathrm{OH}\right)_{3} \mathrm{CNH}_{2}$ を用いて $\mathrm{pH}$ を調整 した人工海水を用いる例が多い。このよらな人工海水中で，アサクサノリ・セイヨウハバノリ・アオサな ぞの紅・褐・緑藻の光合成を測定すると，トリス無添加の人工海水中に打壮るり光合成速度が顕著に增大 しているのが認められた。

この原因をしらべるために，トリス濃度・トリス添加後の経日経過・重炭酸塩添加の有無・容器の密閉程 度などの各項目について，それぞれ海藻の光合成速度・培養液の $\mathrm{pH}$ 変化・全炭酸含量の変化などを測定 した。

その結果，トリスを添加することで炭酸塩・重炭酸塩を含まない場合でも，人工海水中の全炭酸含量が 増加すること, その増加の程度はトリス添加後の 経日経過とともに増大すること, しかしその程度は容器 の密閉の程度でも変化することなどがわかった。

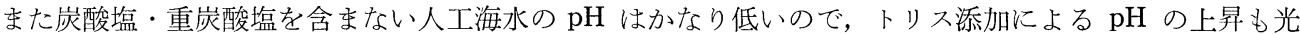
合成促進に笴与している。ただし適当な炭酸源の供給がない場合，単なる $\mathrm{pH}$ の上昇だけでは光合成の促 進が説明できない.

上記の点から, トリスは $\mathrm{pH}$ の適当な上昇と周囲の空気中からの $\mathrm{CO}_{2}$ ガスの吸収による炭酸源増加の 雨要因によって, 人工海水中に批る海藻の光合成速度を増大させるものと考えられる.（水産大学校） 